\title{
WOMEN'S ROLE IN MITIGATION AND DISASTER MANAGEMENT
}

\author{
Lilik Sumarni*, Endang Rudiatin \\ Faculty of Social Science and Political Science, University of Muhammadiyah Jakarta \\ Jl. KH. Ahmad Dahlan Ciputat Cirendeu Ciputat Timur, 15419 \\ *E-mail: liliksumarnil@gmail.com
}

\begin{abstract}
The impact of climate change caused by global warming is currently one of the trending topics in various media and it is an extremely serious threat to human security. Forest fires, floods, landslides and changes in lifestyles to survive natural disasters are the very significant contributing factors to poverty rates in various parts of the world. The London School of Economics and Political Science conducted a study of 141 countries affected by disasters in the 1981-2002 period and found a close link between natural disasters and women's socioeconomic status. Data from the National Agency for Disaster Management (BNPB) states that women have 14 times of risk for becoming victims of disasters compared to adult men. Women become the most victimized because women prioritize children and their families rather than saving themselves. Although women bear more risks to climate change, women can also have the principal opportunity and role in implementing climate change mitigation adaptation, namely by making women actors in disaster mitigation and drivers of change in parallel to their strong responsibilities to their families. By providing adequate knowledge for women about adaptation and mitigation of disasters, the women can turn themselves to be the strategic activists in coping with disasters for communities living in disaster-prone areas.

This study is a comparative discussion of three research results to obtain an overview and find solutions to women's problems from the consequences of climate change, which is a study by changing women from being the most victims of natural disasters to becoming the driving actor for families and communities in overcoming disaster and her ability to survive the postdisaster situation. The conclusion is the three levels of gender roles related to climate change to increase women's adaptive capacity. An adaptation strategy needs the form of 1. Increasing the role of women in the political arena. It is a crucial issue because women's rights can be protected by their presence and role, as well as women in guarding policies. 2. Increasing the role of women in the realm of education. Education is no less important than politics because education will provide a foundation for understanding and self-confidence, bargaining and personal branding for women so that their presence in society will be recognized and will no longer be discriminated. 3. Cultural reconstruction based on gender equality is very important because so far, the notion of patriarchy is still inherent in our culture. Many perspectives are cooptated on the statement that superior (men) are stronger then give rise women mythos that is said to be weak (women). In reality, the presence of women is still fundamental to the aspect of maintaining the economy and education for the continuation and the quality of the life in the society.
\end{abstract}

Keywords: Women, Mitigation, Disaster Management 


\section{INTRODUCTION}

The impact of global warming and the greenhouse contributed significantly to the increase in natural disasters. Hurricanes, landslides, floods, forest fires, high waves and drought are consequences to global management. The media is never devoid of news about natural disasters. Every year 250 million people become victims of nature. The more frequent disasters will be hard to predict. Large scale disasters compared to the previous ones made it hard to provide rescue measures for victims. Our earth is very vulnerable to climate change and human activities that harm nature due to the massive exploitation of natural resources.

All of these have contributed to the process of provoking disasters. It estimated that there are more than 6,000 disasters in the last twenty years and then 252 million people world are affected by various types of natural disasters. It is not the numbers when adding earthquakes, volcanic eruptions, and various other disasters that not related to climate change. In Europe, media coverage in 2019 was marked by protests carried out by children with their motto "Friday for Future" accusing political leaders of negligence and dragging the world into the climate crisis. "The Global Strike 4 Climate took place in 110 cities in Australia, Friday (20/9), including Sydney and the capital city of Canberra. In New York, Greta Thunberg is campaigning on climate change and is the first Swedish teenager to hold a "School Strike for Climate". Likewise, Indonesia is a country that has 500 volcanoes and 127 of them are in active condition. Furthermore, it has 295 plate faults in the sea and land, which certainly makes the country as the area with the high risks of experiencing disasters. In the Aceh Tsunami disaster, data shows that $55-70 \%$ of the victims who died were women.

Various problems related to the role of women and climate change disasters have not optimally implemented. Gender issues that rise include subordination (degrading the role of women), violence, marginalized rights, double burdens and labelling as well negative that continue to carry out against women have made women space for movement so limited. In the entity of women, it believes women are mentally stronger in the dual roles they play.

There are at least three hot issue categories, namely gender responsive, gender biased, and gender neutral. Responsive gender is about partiality in the form of activities or conditions in support of the implementation of gender 
roles, for example in the management of the posts, including women's equipment such as sanitary napkins, toilets for women, nursing rooms, including the issue of impartiality in the provision of open and non-separate toilets for men women and men, the feasibility of health services, and sometimes women's lack of interaction and access to disaster activities on the grounds that they are already represented by their spouse or father or brother and there are many other problems that show the minimality towards women's participation and access in response and handling to the post disaster situation. Women should also be given socialization or access to knowledge regarding disaster management, evacuation routes, warning system for socialization through the head of neigborhood and public figures as well as public service and other institutions that involve women not only men.

In this case, the National Agency for Disaster Management and the Provincial / District / City Agency do several things related to gender responsiveness, such as earthquake simulations conducted in schools, training in tent installation involving men and women, psychosocial clinics or trauma healing for men and women, MSME assistance for women, Asmara Rooms, disaggregated data collection, distribution of women's interactions in posts management. However, there are still many obstacles continues to be clustered under the gender issues in disaster management locations and there are also many opportunities that can be implemented in the fulfillment of the gender in every aspect of disaster management stages. All of this require "willingness" and commitment from all disaster management stakeholders to realize the gender mainstreaming in disaster management (Pengarustamaan Gender in Disaster Management, 16 March 2017).

This study will present a comparative analysis of three research results that use several relevant approaches in revealing post-disaster women due to climate change and the dual roles that burden women with the above problems as well as findings and recommendations that can provide our picture and possible alternative solutions references in pressuring institutions that have authority and various organizations that promote women's rights and influence the gender mainstreaming. 


\section{Theoretical Analysis}

Gender is the interpretation created

by the society about the roles, functions and responsibilities between women and men which are formed over a long period of time in accordance with the times and the environment in which the community lives so that it becomes a culture that can affect interactions between communities, including interactions between men and women (Fakih, 1996). Gender is a trait to identify (Rochmayanto and Kurniasih, 2013). Moreover, Gender is also the differences between men and women in terms of social and culture, values and behavior, mentality and emotions, and other non-biological factors (Wijaya, 1996).

Gender is different from sex, although etymologically it means the same as sex, namely gender. In general, sex is used to identify differences between men and women in terms of biological anatomy, while gender concentrates on social, cultural, and other non-biological aspects. The study of sex emphasizes the development of biological aspects and chemical composition in the body of men and women, while gender studies emphasize the development of aspects of a person's masculinity and femininity. Gender can undergo changes in time, place and social class, while sex is permanent (Ollenburge, 2002).

Gender is one of the considerations in determining roles in natural resource management, known as gender roles. The gender role is a concept of behavior that is taught in every society, community and certain social groups that make certain activities, duties and responsibilities perceived as the roles of women and men (Fakih, 1996). Roles, at the end of the day are given to be played and fullfilled individuals. Gender roles are roles played by men and women according to their status, environment, culture and community structure (Fakih, 1996).

Fakih (1996) explains that there are 3 (three) categories of gender roles, namely: 1. Productive roles are the roles played by women and men to obtain cash payments, including market production at an exchange rate and household or subsistence production at a use value. For example, work activities in the formal and informal sectors; 2. Reproductive roles are the roles related to the responsibility of caring for children and domestic duties to ensure the maintenance and reproduction of labour which is related to the continuity of labour. Example: giving birth, caring for and caring for children, washing, cleaning the house, repairing clothes and so on; 3 . 
The role of community and political management consists of 2 (two) categories, namely: a. The role of community management (social activities), includes all activities in the community as an extension of the reproductive role, voluntary and without pay; b. The role of political management, namely the role in community organizing at the formal political level, is usually paid (directly or indirectly), and increases power or status.

If managed properly, the role of gender can be a community adaptation strategy to climate change, but if not managed properly, it can increase vulnerability. Referring to the gender roles above, gender roles in this study can be seen by discussing these three roles which include reproductive, productive, and community management and political activities.

\section{RESULTS AND DISCUSSION}

By taking these results of the following three studies into account, we will look at the extent of the problems and the roles of women in the adaptation process of disaster situation and management, as follow:

Table: The Comparison of Researches

\begin{tabular}{|c|c|c|}
\hline No. & Titles/Researcher's Names & Results \\
\hline 01 & $\begin{array}{l}\text { The Role of Gender in Adaptation to } \\
\text { Climate Change in Mountainous } \\
\text { Ecosystems in Solok District, West Sumatra } \\
\text { (The Role of Gender on Climate Change } \\
\text { Adaptation in the Mountainous Ecosystem } \\
\text { at Solok District, West Sumatra) } \\
\text { Yanto Rochmayanto1 \& Pebriyanti } \\
\text { Kurniasih, Center for Climate Change and } \\
\text { Policy Research and Development Jl. } \\
\text { Mount Batu No. 5. Bogor }\end{array}$ & $\begin{array}{l}\text { The results showed that changes in temperature and rain } \\
\text { patterns gradually changed the productive role so that } \\
\text { women were also responsible for agricultural production } \\
\text { in a larger proportion. Changes in gender roles have } \\
\text { resulted in gender injustice, namely marginalization, } \\
\text { stereotyping, subordination and a double burden for } \\
\text { women. To increase women's adaptive capacity, the } \\
\text { adaptation strategies are needed in the form of: } \\
\text { (1) increasing the political role of women, } \\
\text { (2) increasing the capacity of women in education } \\
\text { formal and non formal, and } \\
\text { (3) cultural reconstruction based on gender equality. }\end{array}$ \\
\hline 02 & $\begin{array}{l}\text { The meaning of the issue of global } \\
\text { warming and the environment in the media } \\
\text { by urban women. } \\
\text { By Billy K. Sarwono, Department of } \\
\text { Communication - Faculty of Social and } \\
\text { Political Sciences, University of Indonesia } \\
\text { Campus, Depok). }\end{array}$ & $\begin{array}{l}\text { There are three groups of informants: } \\
\text { (a) work in relation to the environment, } \\
\text { (b) the work is not related to the environment but cares } \\
\text { about the environment, } \\
\text { (c) the work is not related to the environment and does } \\
\text { not care about the environment. Second, the majority of } \\
\text { understanding of environmental preservation is limited } \\
\text { to keeping the environment clean. Third, groups whose } \\
\text { professions are not related to the environment interpret } \\
\text { this phenomenon in a global context and their concern } \\
\text { for climate change is still limited to a lifestyle. The } \\
\text { meaning of informants is in line with media coverage } \\
\text { that positions women in the domestic sphere. This group }\end{array}$ \\
\hline
\end{tabular}




\begin{tabular}{|l|l|l|}
\hline \multicolumn{1}{|c|}{} & $\begin{array}{l}\text { believes that environmentally friendly socialization is } \\
\text { the responsibility of women starting from home. On the } \\
\text { other hand, groups with a profession related to the } \\
\text { environment interpret global warming in the local and } \\
\text { national context. Informants believe that socialization of } \\
\text { environmental care does not always start at home, but is } \\
\text { carried out intensively through the media, government, } \\
\text { schools and activities in the workplace. }\end{array}$ \\
03 & $\begin{array}{l}\text { The Role of Women in Disaster } \\
\text { Management: A Study to Improve } \\
\text { Humanity in the Soul of Women in Disaster } \\
\begin{array}{l}\text { Management. By } \\
\text { Afifatul munawiroh } \\
\text { Pra cadres IMC (Intellectual Movment } \\
\text { Community) IAIN Jember, } \\
\text { Alumni of Darul Ulum Islamic Boarding } \\
\text { School and Student of HES Study Program } \\
\text { at IAIN Jember }\end{array} \\
\text { of humanity in women's spirit, secondly, the } \\
\text { development of a sense of humanity in women's spirit in } \\
\text { disaster management, the third is the realization of } \\
\text { developing a sense of humanity in women's spirits in } \\
\text { disaster management }\end{array}$ \\
\end{tabular}

Based on the theoretical basis (Fakih: 1996) there are 3 (three) categories of gender roles, the three results of the above research will be analyzed as material for discussion and study as follows:

Whereas research conducted shows changes in temperature and rain patterns slowly change the productive role so that women are also responsible for agricultural production in a larger proportion. Seeing this, of course we can look at the economic problems, namely women face multiple responsibilities and burdens, women are required to work and generate income in addition to their responsibilities as a mother and wife.

It becomes a big problem, when the husband is no longer able to provide sufficient income for the family. Especially when the husband dies leaving behind several children whose needs are met, both in terms of clothing, food and shelter, including health, education and social access needs. Of course, this will not be easy for women. Many women work in the agricultural industry, even bringing their children. This also creates new problems for the child development.

However, women have a big share in the agricultural sector. Adnan Purichta Ichsan in Women, Agriculture, and Indonesian Economic Power writes that the role of women in economic development is no less important than men, in the agricultural sector, the data proves that the Indonesian agricultural sector cannot be separated from the role of female farmers whose numbers are greater than male farmers, which is around 76, $84 \%$

(ST2 
(https://timurmedia.com/perempuan-

pertanian-dan-kekuatan-ekonomi-

indonesia/). This shows that women cannot be underestimated in the success of production in the agricultural industry. For example, the results of research conducted by Marlina Damatun and friends; By using 30 respondents, it was shown that women's working time for harvesting was 2.86 hours / day, planting 1.8 hours / day, tillage 1.7 hours / day, weeding 0.46 hours / day, seeding 0.4 hours / day, fertilizing 0.26 hours / day and controlling pests and diseases 0 hours / day (AgriSocioEkonomi Unsrat, ISSN 1907-4298, Vol; 13 Number 1A, January 2017).

The discourse on understanding the subordination of women and the superiority of men seems to have shifted in accordance with the changing times. Thoughts that always place men as the main role than women, despite the fact that in society many men do not play a role in accordance with their function as head of the family. For example, in tea plantations, Cianjur, West Java and other areas. However, with the large contribution of women in agriculture, women farmers in Indonesia still experience many problems and obstacles. For example, around $40 \%$ of small-scale farmers are women, amounting to 7.4 million in 2013 (Leong Yee Ting:
Women Farmers Facing Various Barriers, binadesa.org, 14 November 2017). Women's contribution is in almost all production stages but they are deficient access to land services, credit and extension services. This shows that in 2013 only one-third of land that had been certified was held in women's names, even though there was already a 1974 Marriage Law which regulated ownership of wives. However, it is rarely practiced in making certificates because of the low level of education and the patriarchal mindset that is very dominant so that it puts men's names on the certificate.

Various problems faced by women have led to changes in gender roles that have resulted in gender injustice, they are marginalization, stereotypes, subordination and a double burden for women. Therefore, to increase women's adaptive capacity, adaptation strategies are needed in the form of:

(1) Increasing the political role of women.

The Ministry of Women's Empowerment and Child Protection of the Republic of Indonesia (Kemen PPPA RI) in order to increase the $30 \%$ figure of women's representation in the legislative sector in the 2019 General Election said that to increase $30 \%$ of women's representation in parliament, is the 
government's effort to protect women's participation rights in politics, to rise from being left behind in various fields of development, such as politics, economy, law and other fields. This effort also supports the development progress in other fields, as well as improving people's welfare and realizing gender equality, in order to catch up with other countries. This is marked by the increase in the Gender Development Index (IPG) and the Gender Empowerment Index (IDG) (Yohana Yembise: Remarks on Strengthening the Capacity of Women Legislative Candidates in the 2019 Election, Publications and Media of the Ministry of Women's Empowerment and Child Protection: 2019)

Furthermore, the minister also said that in order to increase this figure, the PPPA Ministry has issued PPPA Ministerial Regulation Number 15 Year 2015 regarding the Grand Design for Increasing Women's Representation in the DPR, DPD and DPRD (Indonesian Parliments) in the 2019 Election. Women's representation in the political sector is a national commitment in the 2015 RPJMN - 2019, as well as international commitments in the order of the 5 Sustainability Development Goals (SDGs). This commitment is the basis of the Planet
50:50 Gender Equlity agenda in 2030, which was established by the United Nations (UN). The representation of women in parliament is the responsibility of all stakeholders, both at the center, governors and regents / mayors throughout Indonesia. For this reason, we need to work together to encourage and prepare female cadres, both in quality and quantity, to become legislative candidates in the 2019 Election. One of the implementation programs is the arrangement of training for female political facilitators in 34 provinces; leadership training for potential women candidates for regional head; gender perspective national political education; training for state defense women; rural women's leadership training; strengthening the capacity of women legislative candidates at the central and regional levels (Yohana Yembise: Message to Strengthening the Capacity of Women Legislative Candidates in the 2019 Election, Publications and Media of the Ministry of Women's Empowerment and Child Protection: 2019).

The efforts that have been taken by the PPPA ministry will not be successful without the participation of all community members in the form of a synergy management model that involves all stakeholders, so that program 
implementation can be carried out in the practical level in the field to the family level.

(2) Increasing the capacity of women in education.

Formal and non-formal education is very crucial in solving and finding solutions to almost all women's problems. The fulfillment of access to education for women will provide enthusiasm and independence for women in all fields. A good education will be very beneficial for a mother to educate their children. Brolin (1989) explains that life skills constitute a continuum of knowledge and aptitude that are necessary for a person to function effectively and to avoid interruptions of employment experience. Thus, life skills can be expressed as skills for life (experience). Not only having certain abilities (vocational jobs), but he must have basic functional abilities such as reading, writing, calculating, formulating, and solving problems, managing resources, teamwork, continuing to learn in the workplace, using technology ( Directorate General of PLS, Directorate of Technical Personnel, 2003).

These skills include conceptually, including the first, self-awareness or personal skills, secondly, thinking skills or academic skills, third; Social skills (social skills) and the fourth vocational skills (vocational skills) or often called vocational skills that are linked to a particular job or are specific (specific skills) or technical skills (technical skills). Life skills program includes learning to know; is how women get education so they have broad knowledge, learning to do is how women can do something, learn something so that they are able to do something that is beneficial for themselves and their environment. Learning to live together is an opportunity for women to learn and adapt and live together with other people; correctlu, they must be given the opportunity to contribute to the institutions in society. The purpose of life skills education in the life skills education guidelines issued by the Directorate of Technical Personnel, the Directorate General of Out-of-School Education, Ministry of National Education (Ditjen PLS, 2003) is Life Skills Education organized through non-formal education with the aim of improving skills and knowledge, and attitude of the citizens in learning in certain fields of work / business according to their talents, interests in physical and mental development as well as the potential of their environment, so that they have the ability to work or try independently which can be used as 
provisions to improve the quality of life.

(Dadang Yunus L, Life Skills in Empowering Women Heads of Families (Pekka) to Increase Income and Entrepreneurial Independence https://ejournal.upi.edu/index.php/pls/articl e/view/.

(3) Cultural reconstruction based on gender equality

Talking about gender, we will talk about the relationship conducted between men and women. Some of the factors that are very important when discussing about this relations are education, the presence of women in society, the presence of women in the political arena which is always related to the socio-cultural context. The thinking of society that already considers men who are stronger to dissolve women have cultured and made something reasonable because they tolerate the physical appearance of women who are indeed more refined. However, in the development and pattern of problems in the community, there are many problems of breastfeeding and other problems which result in many men who behave like women and women taking over the role of the head of the household, such as earning a living and school fees for their children. And in the end, women must be protected and they should have the same rights and opportunities which are expected to create a balance of women's productivity not only in the domestic area but also in the public sphere. Therefore, a long struggle is still needed in terms of instilling in society a way of thinking how women can also play a role or be stronger in terms of emotion and accuracy than men. A mother who performs many roles in the family, women who are left with socio-economic problems in the families, are ones of the examples when women can initiate the quick actions and solutions while being considerate to the family members in order to save the life of the family and to survive the difficult crcumstances.

\section{CONCLUSION}

The conclusion from the above discussion which is the three levels of gender relations related to climate change to increase women's adaptive capacity requires an adaptation strategy in the form of:

1. Increasing the role of women in the political arena. This is a crucial issue because women's rights can be protected by the presence and participation of women in guarding policies. So that it can provide equal space for the presence of women in the industry in terms of women who are 
active in the public sphere or women who replace the head of the family.

2. Increasing the role of women in the realm of education. Education is something that is no less important than politics, because education will provide a foundation for understanding and self-confidence, bargaining and personal branding for women, so that their presence in society will state that they are not discriminated against.

3. Cultural reconstruction based on gender equality is very important because so far patriarchy is still attached to the culture in our country. Many perspectives that are cooptated on the statement that superior (men) are stronger then give rise to imperior

\section{REFERENCES}

Rochmayanto, Y., \& Kurniasih, P. (2013). Peranan Gender dalam Adaptasi Perubahan Iklim pada Ekosistem Pegunungan di Kabupaten Solok, Sumatera Barat. Jurnal analisis kebijakan kehutanan, 10(3), 203-213.

Ollenburger, B. C. (2014). Ollenburger Responds. Mennonite

Life, 60(September 2005).

Walangitan, H. D. (2017). Kajian Sistem Perladangan di Kabupaten Bolaang Mogondow (Studi Kasus Perladangan di Kphp Wilayah II Kabupaten Bolaang Mongondow). AGRISOSIOEKONOMI, 13(1), 45-54. which is readily said to be weak (women). However, in reality the presence of women who are expended to maintain food security and aspects of family education plays an important and fundamental role.

Ditjen, P. L. S. (2003). Program Life Skills Melalui Pendekatan Broad Based Education (BBE). Jakarta: Direktorat Tenaga Teknis Depdiknas.

Ari, M. K. H. A. A., Idayanti, R., \& Munawiroh, A. (2019). Peran Perempuan dalam Penanganan Bencana: Studi Meningkatkan Rasa Kemanusiaan Pada Jiwa Perempuan dalam Penanganan Bencana. AN-NISA: Jurnal Studi Gender dan Anak, 12(1), 583-595.

Sarwono, B. K. (2010). Pemaknaan Isu Pemanasan Global dan Lingkungan di Media oleh Kaum Perempuan Urban. Jurnal Ilmu Komunikasi Terakreditasi, 8(2), 178-190. 
Perempuan, Pertanian, dan Kekuatan Ekonomi Indonesia (Dian Novita Susanto, 2019) (https://timurmedia.com/perempuanpertanian-dan-kekuatan-ekonomiindonesia/)

Perempuan Petani Menghadapi Berbagai Rintangan (Gina Nurohmah, 2017)

(https://binadesa.org/perempuan-petanimenghadapi-berbagai-rintangan/)

Yohana Yembise: Sambutan Acara Penguatan Kapasitas Perempuan Calon Legislatif pada Pemilu 2019, Publikasi dan Media Kementrian Pemberdayaan Perempuan dan Perlindungan Anak: 2019

(https://www.kemenpppa.go.id/index.php/ page/read/29/1837/tingkatkanpartisipas iperempuan-dalam-pemilu-2019)

Dadang Yunus L, Kecakapan Hidup (Life Skills) Dalam Pemberdayaan Perempuan Kepala Keluarga (Pekka) Untuk Peningkatan Pendapatan Dan Kemandirian Berwirausaha (https://ejournal.upi.edu/index.php/pls/ article/view/) 